\title{
Correction to: A solution for funding the development of technology in oilwell drilling
}

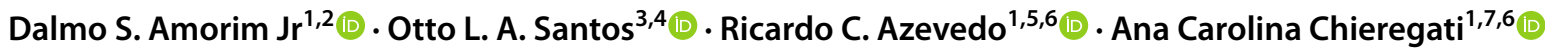

Published online: 6 April 2021

(c) The Author(s) 2021

\section{Correction to: \\ Journal of Petroleum Exploration and Production Technology https://doi.org/10.1007/s13202-020-01030-z}

In the original publication of the article, the following sentence contains a error; the correct sentence should read as "By generating a high expectation to products or procedures under development, clients might be tempted to test them".

The word "templated" has been corrected to "tempted".

Open Access This article is licensed under a Creative Commons Attribution 4.0 International License, which permits use, sharing,

\begin{abstract}
adaptation, distribution and reproduction in any medium or format, as long as you give appropriate credit to the original author(s) and the source, provide a link to the Creative Commons licence, and indicate if changes were made. The images or other third party material in this article are included in the article's Creative Commons licence, unless indicated otherwise in a credit line to the material. If material is not included in the article's Creative Commons licence and your intended use is not permitted by statutory regulation or exceeds the permitted use, you will need to obtain permission directly from the copyright holder. To view a copy of this licence, visit http://creativecommons. org/licenses/by/4.0/.
\end{abstract}

Publisher's Note Springer Nature remains neutral with regard to jurisdictional claims in published maps and institutional affiliations.

The original article can be found online at https://doi.org/10.1007/ s13202-020-01030-z.

Dalmo S. Amorim Jr

dalmo.amorim@gmail.com

1 Mineral Sciences, USP - University of São Paulo, São Paulo, Brazil

2 Petroleum Engineering, Department of Petroleum and Mining Engineering, USP - University of São Paulo, São Paulo, Brazil

3 Petroleum Engineering, Colorado School of Mines, Golden, CO, USA

4 Petroleum Engineering, Louisiana State University, Baton Rouge, LA, USA

5 Petroleum Engineering, University of Stavanger, Stavanger, Norway

6 Mining and Petroleum Engineering Department, USP - University of São Paulo, São Paulo, Brazil

7 Petroleum Engineering, Aalborg University, Aalborg Øst, Denmark 